\title{
Geology of the
}

Calamity Peak Area,

\section{Custer County, South Dakota}

By D. H. Kupfer

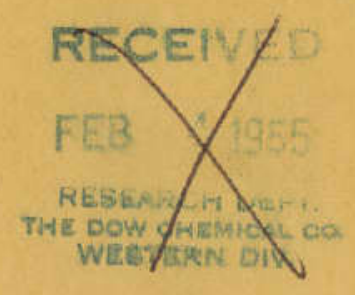

\section{Trace Elements Investigations Report 294}

UNITED STATES DEPARTMENT OF THE INTERIOR GEOLOGICAL SURVEY 



\section{UNITED STATES \\ DEPARTMENT OF THE INTERIOR \\ GEOLOGICAL SURVEY \\ WASHINGTON 25. D. C.}

$\operatorname{AEC}-443 / 5$

January 14, 1955

Mr. Robert D. Nininger, Acting Assistant Director

Division of Raw Materials

U. S. Atomic Energy Commission

16th and Constitution Avenue, N.W.

Washington $25, \mathrm{D}$. C.

Dear Bob:

Transmitted herewith are three copies of TEI-294, "Geology of the Calamity Peak area, Custer County, South Dakota," by Donald $\mathrm{H}$. Kupfer, July 1954.

We are asking Mro Hosted to spprove our plan to publish this report as a Geological Survey bulletin.

Sincerely yours,

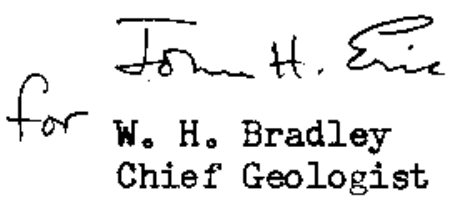

RECEIVED

$\mathrm{FEB} \rightleftharpoons 1955$

RESEAFIL $r i, \ldots+\cdots$ THE DOW CHEMICAL DO WESTERN DIV 
Geology and Mineralogy

This document consists of 43 pages, including page 18a, plus 1 figure.

Series A

UNITED STATES DEPARTMENT OF THE INTERIOR

GEOLOGICAL SURVEY

GEOLOGY OF THE CALAMITY PEAK AREA,

CUSTER COUNTY, SOUTH DAKOTA

By

Donald H。 Kupfer

July 1954

Trace Elements Investigations Report 294

This preliminary report is distributed without editorial and technical review for conformity with official standards and nomenclature. It is not for public inspection or quotation.

This report concerns work done on behalf of the Division of Raw Materials of the $U_{0}, S_{0}$ Atomic Energy Commission. 
Argonne National Laboratory , . . . . . . . . . . . . . . . . . . . . . .

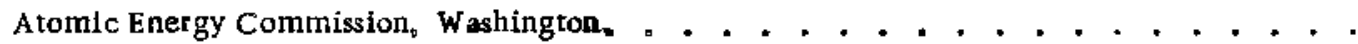
Battelle Memorial Institute Columbus. . . . . . . . . . . . . . . . . . . . . Carbide and Carbon Chemicals Company, $\mathrm{Y}-12$ Area . . . . . . . . . . . . . . . Division of Raw Materials, Albuquerque . . . . . . . . . . . a . . . . . . . . Division of Raw Materials, Butre. . . . . . . . . . . . . . . . . . . . . . . Division of Raw Materials, Denver . . . . . . . . . . . . . . . . . . . . . . Division of Raw Materíals, Douglas. . . . . . . . . . . . . . . . . . . 。 Division of Raw Materials, Hot Springs . . . . . . . . . . . . . . . . . . . Division of Raw Materials, Ishpeming . . . . . . . . . . . . . . . . . . . . Division of Raw Materials, Phoenix . . . . . . . . . . . . . . . . . . . Division of Raw Materials, Richfield . . . . . . . . . . . . . . . . . . . .

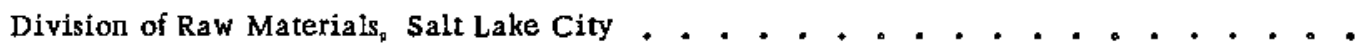
Division of Raw Materials, Washington a . . . . . . . . . . . . . . . . . . Dow Chemical Company, Pittsburg . . . . . . . . . . . . . . . . . . . . . Exploration Division, Grand Junction Operations Office . . . . . . . . . . . . . . Grand Junction Opera tions Office . . . . . . . . . . . . . . . . . . . . . . National Lead Company, Winchester .. . . . . . . . . . . . . . . . . . . . Technical Information Service, Oak Bidge . . . . . . . . . . . . . . . . . . Tennessee Valley Authority, Wilson Dam , . . . . . . . . . . . . . . . . . . U. S. Geological Survey:

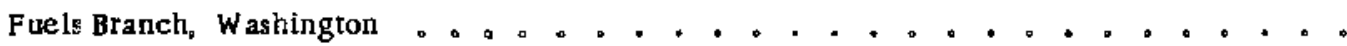
Geochemistry and Petrology Branch, Washington, . . . . . . . . . ..... Geophysics Branch, Washington ....... . . . . . . . . . . . . . . . . . Mineral Deposits Branch, Washington........................... E. $\mathrm{H}_{\circ}$ Bailey, Menio Park . . . . . . . . . . . . . . . . . . . . . .

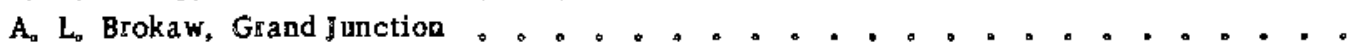

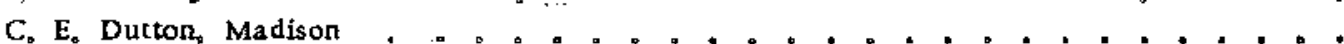

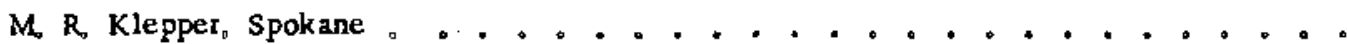
A. H. Koschmann, Denver o............................. R. A. Laurence, Knoxville, . . . . . . . . . . . . . . . . . . . . . L. R. Page, Washington . . . . ............................

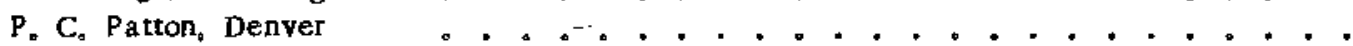
J. Fo Powers, Sait Lake City . . . . . . . . . . . . . . . . . . . . . . . . Qo $D_{o}$ Singewald, Beltsville ............................. A, E Welssenbom, Spokane . . . . . . . . . . . . . . . . . . . . . TEPCO, Denver TEPCO, RPS, Washington, (Including master) 


\section{CONTENTS}

Page

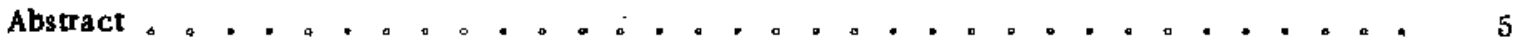

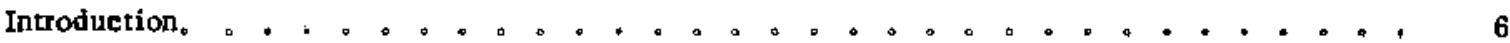

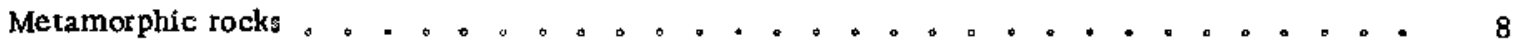

Granitic rocks 。. . . . . . . . . . . . . . . . . . . . . . . . . . . . 10

Granite-pegmatite complex ....... . . . . . . . . . . . . . . . 11

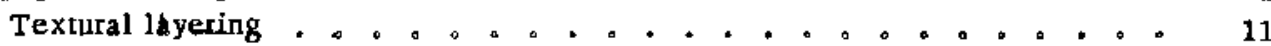

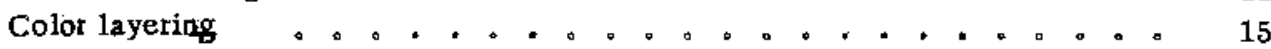

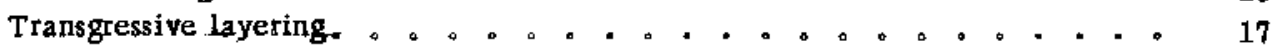

Pegmatite . . . . . . . . . . . . ............... . . . 17

Unzoned pegrnatite. . . . . . . . . . . . . . . . . . . . 20

plagioclase-perthite -quartz pegmatite . . . . . . . . . . 20

Graphic granite-plagioclase-quartz pegmatite . . . . . . . . 20

Perthite and perthite-quart pegmatite... . . . . . . . . 20

Quartz-perthite pegmatite .. . . . a . . . . . . . . . . 20

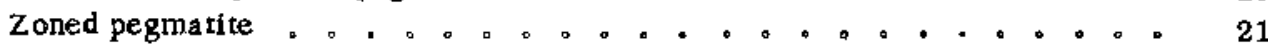

L-5 Na $2.0 .0 . . .0 .0 .0 .0 . . . . . .0 .021$

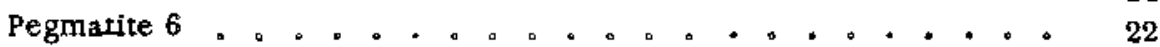

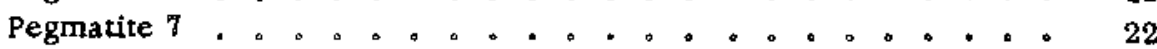

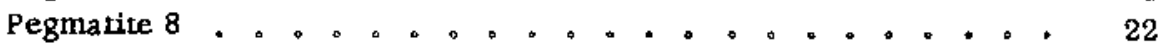

L $-5_{4}$ or Spring pegmatite o. . . . . . . ........ . 23

Pegmarite 12 ...................... . . . . 24

Quartz veins, , . . . . . . . . . . . . . . . . . . . . . . . . . . . 24

Sedimentary rocks 。

Terrace gravels . . . . . . . . . . . . . . . . . . . . . . . . 24

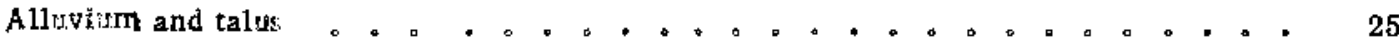

Structure . . . . . . . . . . 。 . . . . . . . . . . . . . . . . . 25

Bedding and schistosity . . . . . . . . . . . . . . . . . . . . 26

Wrinkling and lineation .. . . . . . . . . . . . . . . . . ..... 26

Igneous structures 。. . . . . . . . . . . . . . . . . . . . 28

Calamity Peak granitic mass . . . . . . . . . . . . . . . . 29

Tabular bodies........................... . . . 31

Pegmatites . . . . . . . . . . . . . . . . . . . . . 31

Faults . . . . . . . . . . . . . . . . . . . . . . . . . . 32

Origin of the granitic rocks, . . . . . . . . . . . . . . . . . . . . . . . . 34

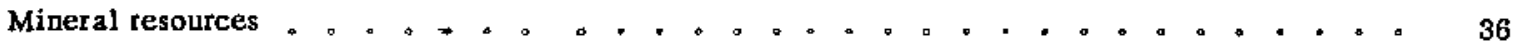

Pegmatites 。. . . . . . . . . . . . . . . . . . . . . . . 36

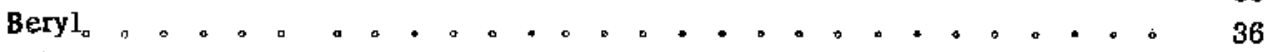

Mica, . . . . . . . . . . . . .......... 37

Feldspat . . . . . . . . . . . . . . ........ a 38

Other pegmatite minerals o. o... . . . . . . . . . . . . . 38

Resources..... . . . . . . . . . . . . . . . . . . . 39

Gold o. . . . . . . . . . . . . . . . . . . . . . . . . . . 39

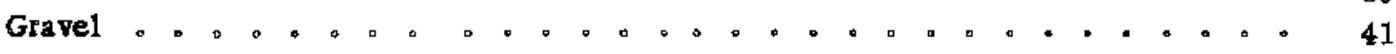

Literature cited . . . . . . . . . . . . . . . . . . . . . . . . . 42 


\section{ILLUSTRATIONS}

Page

Flgure 1. Map of the southern Black Hilis, South Dakota, showing areas mapped in 1946-1950

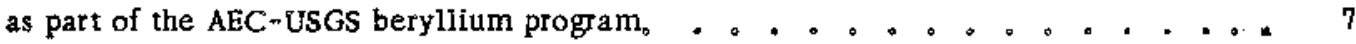

2. Geologic map of the Calamiky Peak area, Custer County, South Dakota . . . . In envelope

3. Geologic sections, Calamity Peak area Custer County, South Dakota . . . . . 9

4. Textural layering in the Calamity Peak mass of granite-pegmatite complex. . . . . 12

5. Pattern of layering in the granite-pegmatite complex of the Calamity Peak area . . 13

6. Color layering in a thick layer of leucocratic soda granite in the Calamity Peak mass + 16

7. Very large wrinkles in schist in the northern part of the area. Regional schistosity and the bedding strike $\mathrm{N}_{0} 60^{\circ} \mathrm{W}$, and dip $50^{\circ} \mathrm{sW}$, (parallel to the crests of the wrinkles). A second schistosity is developed locally that strikes $\mathrm{N}, 67^{\circ} \mathrm{E}$, and dips $40^{\circ} \mathrm{NW}$. (parallel to the axial planes of the wrinkles》. The geology pick rests on a sinuous quartz vein about 1 inch thick that follows the crenulations of the wrinkles. The knobby character of the schist is caused by quartz-siilimanite knots. . . . . . . 2 ?

8. Outcrop in the schist core of the Calamity Peak mass showing schist (dark areas) cutting out upwards against layered granite-pegmatite complex, . . . . . . . . 30

9. Plan. view of contact of pegmatite and schist south of Calamity Peak. The regional trend of the schistosity is locally destroyed and the new schistosity is conformable to the contact ...............................

\section{T ABLES}

Table $1_{b}$ Analyses of granite and pegmatite . . . . . . . . . . . . . . . . . . 14

2. Mineralogy of pegmatite and granite . . . . . . . . . . . . . . . . 18

3. Pegmatite mineral resources...,............... .440 
GEOLOGY OF THE CALAMITY PEAK AREA, CUSTER COUNTY, SOUTH DAKOTA

\author{
By Donald H, Kupfer
}

$\div$

\title{
ABSTRACT
}

An area of $21 / 2$ square miles along the southwest border of the pre-Cambrian granitic rocks complex in the pre-Cambrian core of the Harney Peak region, Black Hills, S. Dak, was mapped to determine the relationship between the granite-pegmatite complex and the pegmatites containing beryl and other industrial minerals. This investigation was part of the $U_{0} S_{0}$ Geological survey's program for the investigation of domestic beryllium resources and was carried out on behalf of the Atomic Energy Commission. The complex of granite and pegmatite occurs in tabular bodies, 50 to 500 feet thick and is composed of alternating layers of leucocratic soda granite and plagioclase-perthite-quartz pegmatite. The layers average 3 inches thick This type of layering is termed textural layering $_{\mathrm{v}}$ The minerals of many of the granite layers are segregated and form still thinner layers termed color layering Gradational with, and sometimes indistinguishable from these are pegmatite or plagioclase-perthite-quary pegmatite fracturefillings or segregations termed transgressive layering The complex is also cut by graphic granite pegmatites, zoned pegmatites, and quartwperthite pegmatites。

Plagioclase-perthite-quartz pegmatite sills in the quartz-mica schist country rock are most abundant near the granitic complex. The pegmatites are intrusive and all gradations are found from the commoniy occurring unzoned pegmatites to the infrequently occurring well-zoned pegmatites. The typical zoned pegmatite contains a fine-grained border zone, biotite and muscovite mica books concentrated in a wall zone, a plagioclase-perthite-quartz pegmatite intermediate zone, and a quartz core containing some large perthite crystals.

Before the formation of the granite -pegmatite complex the metamorphic rocks were folded into a steeply south-plunging synciine and anticline. Wrinkles, lineation, and a secondary schistosity formed at the same time as the granite-pegmatite complex and its related pegmatite sills and quartz veins. 
The plunge of these minor structures parallels the plunge of the pegmatites. Metamorphic grade in the schists, as indicated by size and number of quartz-sillimanite knots, increases from the southwest to the northeast corner of the mapped area A set of northeast trending high-angle faults crosses the area.

The pegmatites mapped contain small resources of feldspar, mica, and beryl. The granitic complex and the graphic granite pegmatites are a potential source of feldspar and silica which could be recovered by flotation, An abandoned gold mine, an abandoned gravel quarry, and gold placer gravels of unknown grade also occur in the area.

\section{INTRODUCTION}

The core of the main Black Hills uplift is composed of pre-Cambrian metamorphic rocks, In the southern part of the core occurs a complex of pre-Cambrian granite and pegmatite. Individual pegmatites intrude the metamorphic rocks surrounding the complex and decrease in number away from the complex. The Calamity Peak area, on the southwest flank of the granite-pegmatite complex, is in the transition zone between areas of predominately granftic and predominately schistose rocks. The Geological Survey chose this transitional area for detailed mapping in order to determine the relations between the larger masses of granite-pegmatite complex and the pegmatites containing beryl and other industrial minerals.

The original program was planned also to determine the presence of any additional beryl-bearing deposits and the size and grade of the beryl pegmatites of the area.

The Calamity Peak are $a_{0} 3$ miles east of Custer, Custer County, $S_{0}$, Dak ${ }_{\mathrm{q}}$, is an area of $2_{\mathrm{q}} 5$ square miles and is a part of the Buckhorn area (28 square miles as defined in the beryllium program carried out on the behalf of the Division of Raw Materials of the $U_{0} S_{0}$ Atomic Energy Commission, by the $U$, $S_{0}$ Geological Survey (fig, 1). The Calamity Peak area includes parts of secs, 16, 17, 19,20, and $21, T, 3 S_{\circ}, R_{\circ} 5 E_{\circ}$ of the Black Hills Base and Meridian. 
TRACE ELEMENTS INVESTIGATIONS


REPORT 294

\section{EXPLANATION}

DIII

PALEOZOIC ROCKS

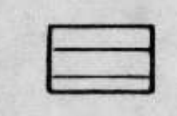

GRANITE-PEGMATITE COMPLEX

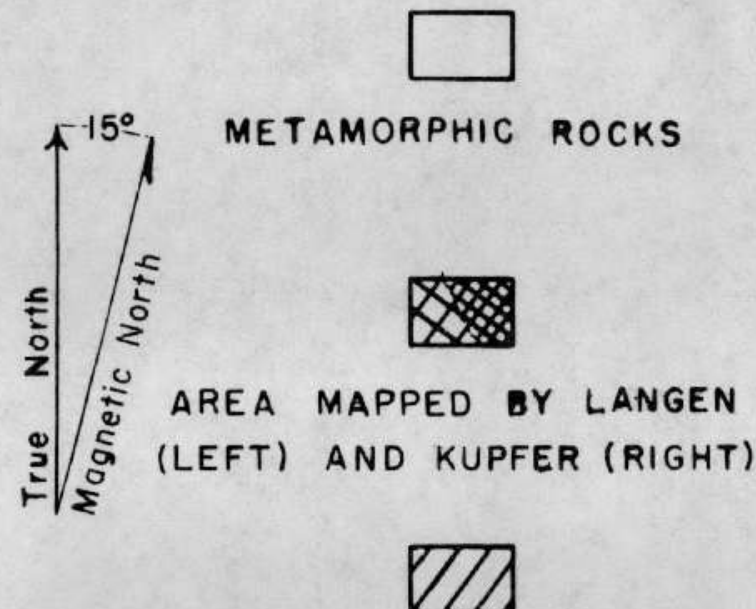

AREA MAPPED OY OTHERS Heavy lines outline areas as defined
in AEC-USGS beryllium program

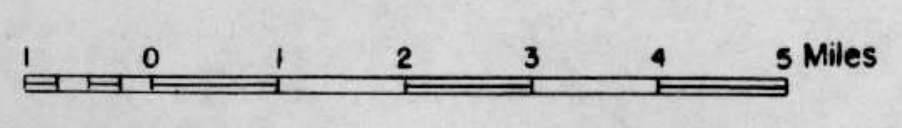

Geology after Darton, N. H., and Paige, Sidney, U.S. Geol. Survey Geol. Allos, Contral Black Hills Folio (no. 219), areal geology map, 1925. 
The maximum relief in the Calamity Peak area is about 600 feet. Bold outcrops and good exposures are common. A thin pine forest with negligible underbrush allows easy access to all parts of the area. Cool to moderate temperatures prevail in the summer and through much of the winter, although occasional periods of extreme cold occur. The average annual rainfall is 18 inches.

The Calamity Peak area was mapped during the summers of 1948 and 1949 on aerial photographs

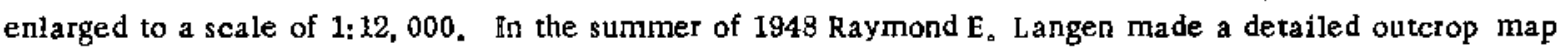
of the pre-Cambrian rocks in 0.6 square mile (fig. $1 \eta_{0}$ In the summer of 1949 the writer examined Langen's notes, briefly checked his map, added the Quaternary deposits, and mapped the additional 1.9 square miles (fig. ID.

\section{METAMORPHIC ROCKS}

Most of the metamorphic rock in the Calamity Peak area occurs around the granite-pegmatite masses, bat large and small, tabular to lenticular, pendants or inclusions of schist (screens) occur within the granitic bodies, and schist underlies the Calamity Peak granite-pegmatite mass (figs, 2 and 3 ).

The principal metamorphic rock of the area is a quartz-mica schist $/$ that generally consists of

_- The petrographic descriptions are based on megascopic examination.

60 to 90 percent quartz, 5 to 30 percent biotite, and a variable amount of muscovite; locally biotite may constitute as much as 90 percent of the rock. (See also Lang and Redden, 1953, p. 1.) Muscoviterich schist is rare, Garnet and sillimanite are common accessory minerals.

A distinctive group of metamorphic rocks called the amphibolite unit by Lang and Redden (1953, P. 2-4) is found near the limits of the Calamity Peak area, but it is not differentiated on the geologic map (fig. 2)。This group includes massive quartzite; mica-poor, quartz schist; quartz-mica schist; medium-grained graphitic schist; quartz-amphibole schist; and massive amphibolite。 


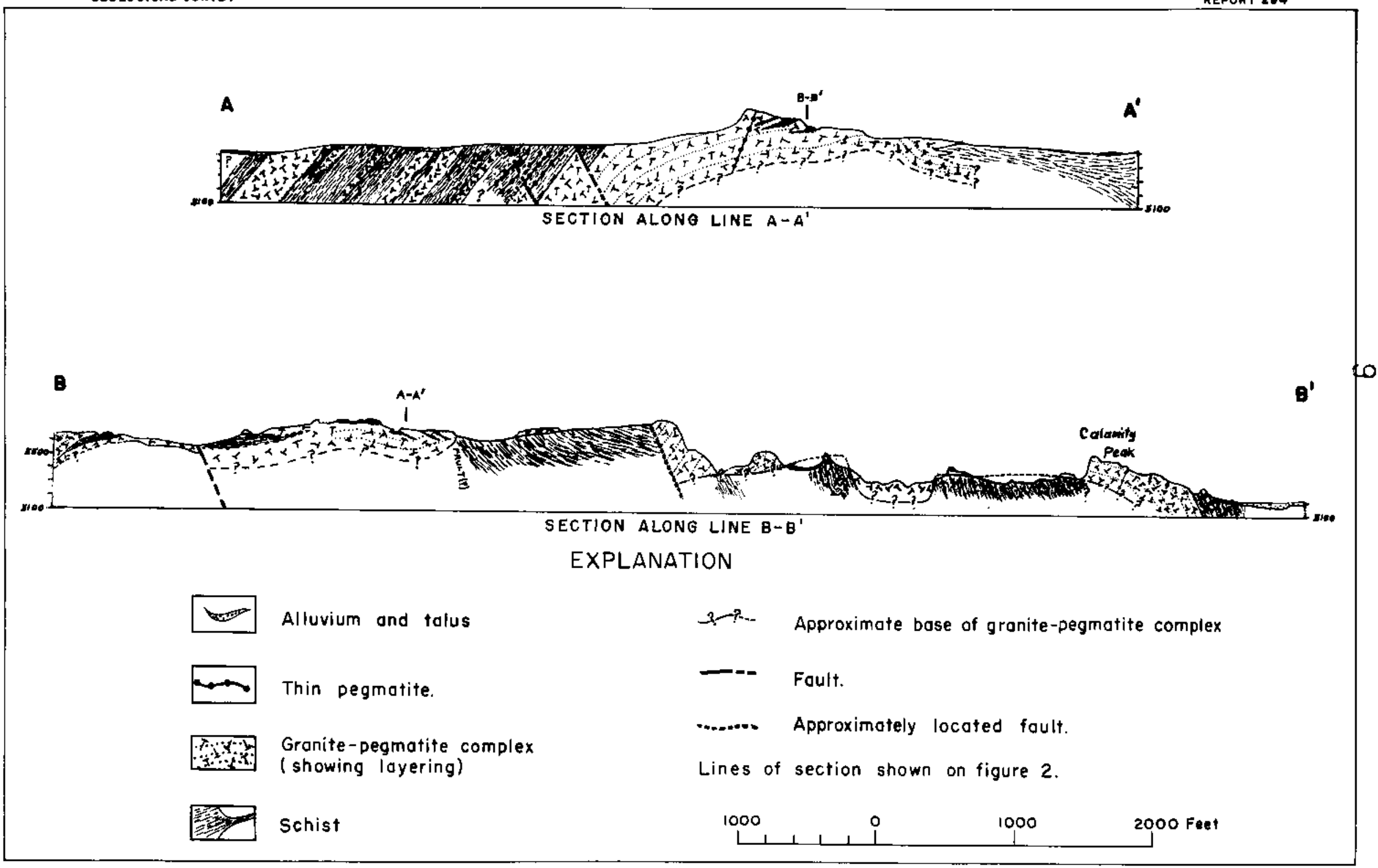

FIGURE 3.- GEOLOGIC SECTIONS, CALAMITY PEAK AREA, CUSTER COUNTY, SOUTH DAKOTA. 
The metamorphic grade of the rocks in the Calamity Peak area increases from southwest to northeast toward the main granite-pegmatite mass of the Black Hills. The quartz-mica schist in the southwest part of the area (sec, 19) contains garnet crystals; the amount of garnet is variable and probably related to the original composition of the beds.

To the northeast of the garnet-rich rocks, the schist contains small aggregates or "knots" of quartz with inclusions of minute sillimanite needles, On weathered surfaces these knots stand out in relief as hard, white discoidal lenses, Harker (1939, p. 229) has briefly described similar quartz-sillimanite aggregates and calls them "knots". "Faserkiesel", or "quartz sillimanitise". The size and number of these quartzsillimanite knots change locally from bed to bed, but to the northeast they increase in size and abundance with a corresponding increase in metamorphic grade. To the southwest (NW $1 / 4 \mathrm{sec}_{\mathrm{o}} 20$ ), the knots are absent in most places, but even where abundant they are less than one-sixteenth inch in diameter. Farther northeast the knots are commonly one weighth inch to one-quarter inch in diameter; in the extreme northeast part of the area (NE 1/4 sec. 17\% the knots are as much as 2 inches in diameter, but knot-free areas also occur. The quartz-sillimanite knots adjacent to the larger granite-pegmatite masses have been altered to muscovite by retrograde metamorphism.

\section{GRANITIC ROCKS /}

Two rock units of granitic composition have been mapped in the Calamity Peak area-- pegmatite and granite-pegmatite complex Gradations between the two units exist.

Three large and numerous small irregular to tabular-shaped bodies composed of the granite-pegmatite complex have been mapped in the Calamity Peak area. The granite-pegmatite complex consists of alternate layers of leucocratic soda granite and plagioclase-perthite-quartz pegmatite. The so-called granite "batholith" of Harney Peak (Darton and Paige, 1925, p. 5\%, to the northeast of the mapped area (fig. 1), is actually a group of separate or interconnected masses of granite-pegmatite complex. In the mapped area the irregular intrusive body at Calamity Peak and the large tabular bodies to the north are typical masses of granite-pegmatite complex.

_ Petrographic descriptions are based on megascopic examination. No thin-sections were examined. Feldspar, determined by oil iminersion. 
Pegmatites of several types occur throughout the area but are most abundant near the borders of the larger granite-pegmatite masses, They form sills in the schist and dikes in the complex.

\section{Granite-pegmatite complex}

The larger granitic masses of the Calamity Peak area contain compositional and textural variations that produce layering of several types. Three main types have been separated. Named after their most prominent field characteristics, they are textural layeriag color layering, and transgressive 1ayering These three types are described separately, but in the field they are found to grade into each other.

$$
\text { Textural layering }
$$

Textural layering (fig, 4), the commonest and most widespread type, is formed by alternate layers of granite and pegmatite. In outcrop, the coarse texture of the pegmatitic layers contrasts sharply with fine-grained texture of the granite layers. This with certain minor exceptions is the layering shown on the geologic map (fig, 2) and in figure $5_{\alpha}$ The layers are commoniy 1 to 12 inches thick, but 1- to 6-foot layers are not uncommon and 25-foot layers have been observed. Most of the contacts between layers are moderately sharp; some are gradational.

The granite layers of the Calamity Peak granite-pegmatite complex form 50 percent of the complex. but farther north (nearer the main granitic mass of the Black Hills they form 80 percent Locally the granite forms as little as 5 percent or as much as 98 percent of the complex.

The granite layers are equigranular leucocratic soda granite in which the grains are less than 0.1 inch in diameter. The rock is highly variable in composition but averages about 40 percent plagioclase (albite or soda rich oligoclase), 30 percent microcline, and 25 percent quartz. Tourmaline, muscovite, biotite, and garnet in places constitute as much as 10 percent of the rock, The granite contains 2.91 percent $\mathrm{K}_{2} \mathrm{O}$ and $5_{\circ} 23$ percent $\mathrm{Na}_{2} \mathrm{O}$ (table 1 )。 


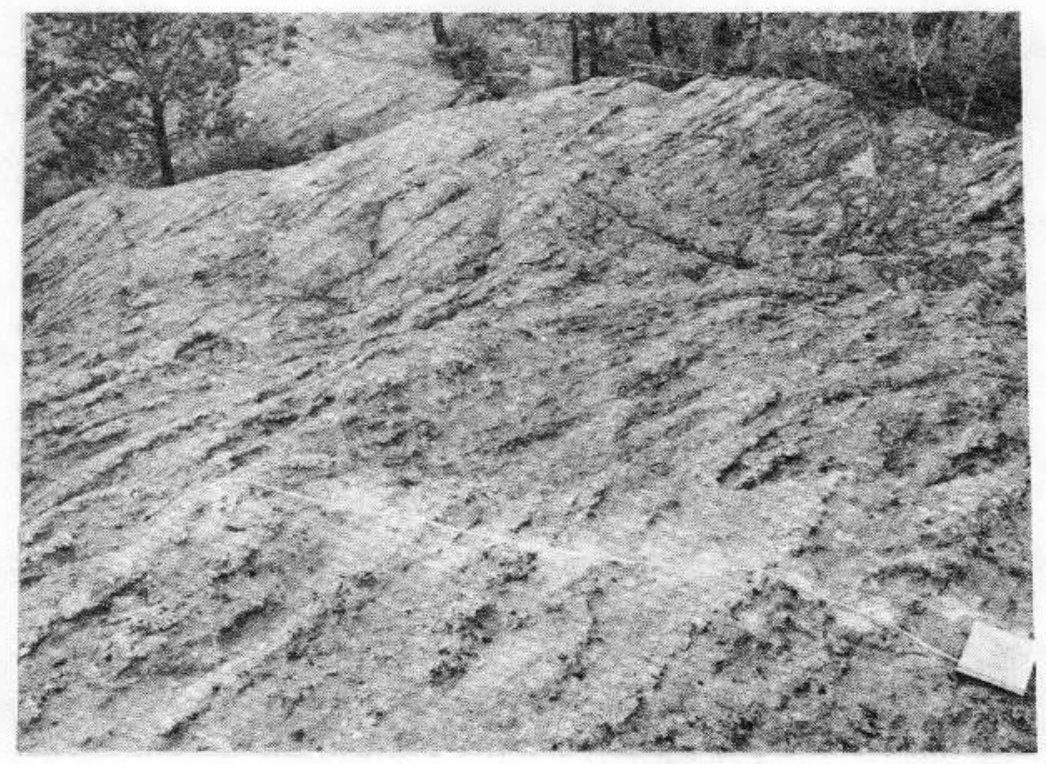

Figure 4.--Textural layering in the Calamity Peak mass of granite-pegmatite complex. Tape line indicates line of samples from location $B$ (table 1 ). The average thickness of the layers is 3 inches. 


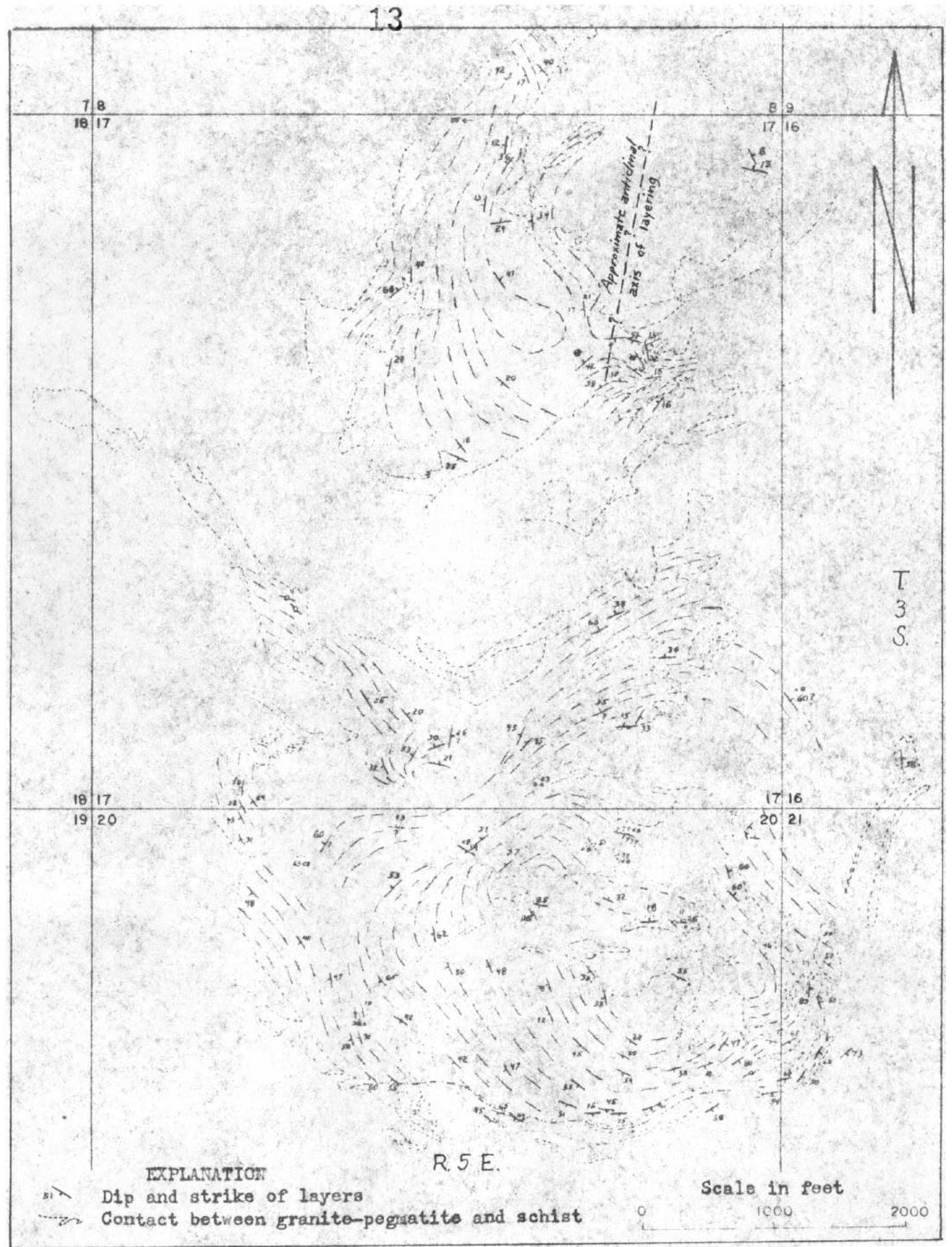

Figure 5.-Pattern of layering in the granite-pepratito ocmplex of the Calanity Poak area. 
Table 1.-Analyses of granite and pegnatite $1 /$.

(compositions in percent)

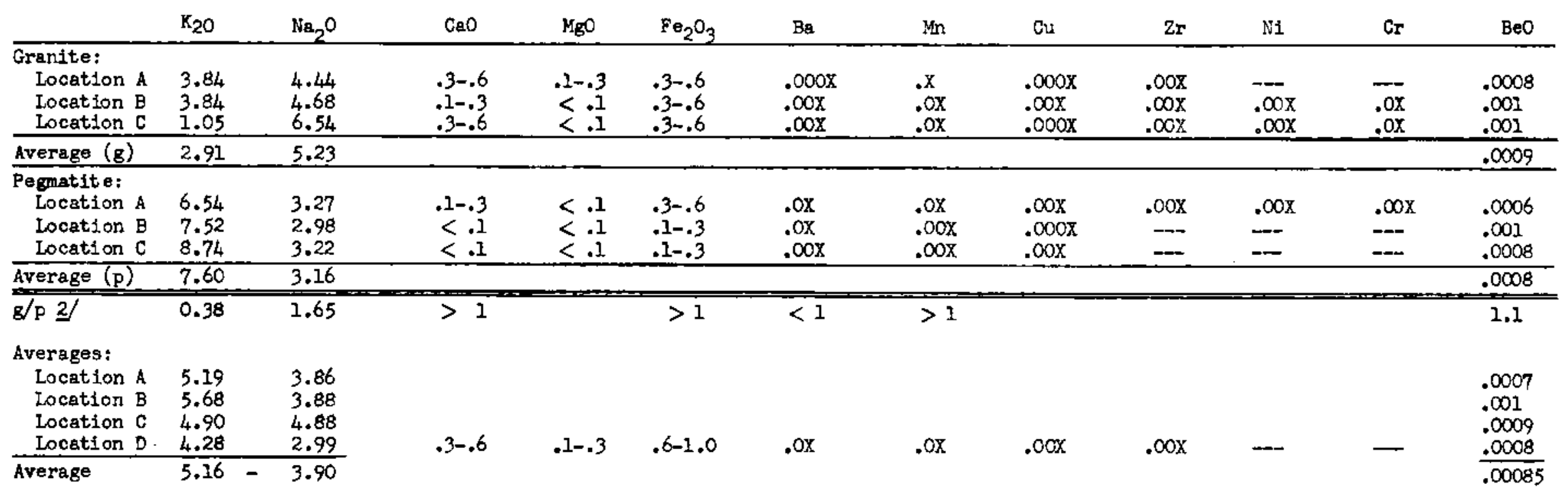

Transgreasive

layer $\quad 3.56 \quad 2.06$

$.3-.6<.1 \quad .3-.6$

$.0 \mathrm{X}$

$.0 \mathrm{x}$

$.00 \mathrm{X}$

- $\quad .00 \mathrm{X}$

$.00 \mathrm{x}$

.002

If Anelyses by U. S. Geological Survey. Sodium, potassium, and lithium deteminations by flame photometer method; S. M. Berthold and

Joseph M. Dowd, analysts. AJl other detemingtions by spectrogrephte plates exposed for general scanning; J. D. Fletcher, analyst.

2/ Average of the granite layers divided by average of the pegnatite layers, approximations by author, rot by anajyst.

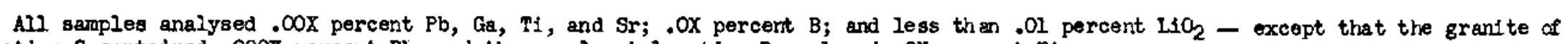
location $C$ contained $.000 X$ percent $\mathrm{Pb}$, and the sample at location $D$ analysed .OX percent $\mathrm{Ti}$.

The samples from locations A and B (fig. 2) are channel samples and the granjte a nd pegnatite parts were analysed separately. The samples from location are chip samples, taken from the center of the lavers to avoid contamination by the gradational ontacts between the layers.

Locations $A$ and $D$ are the same outcrop. Location A has sharply-dff erentiated textural layering that resembles tranggressive layering. The textural layering at location D (5 feet fron location A) is so gradational that the granite and pegnatite layers could not be sampled separately. The transgressive layer (a pegnatite dike) is one of several that cut the outcrop. 
The pegmatite layers of the granite-pegmatite complex are the same rock type as makes up most of the pegmatite sills in the metamorphic rocks and some of the transgressive layering in the complex. This plagioclase-perthite-quartz pegmatite rock is highly variable in composition (table 1) and relative abundance of the characterizing minerals, but despite these variations, the fundarnental mineralogic, textural, and structural similarities of the rock justify its classification as a single type. Most of the plagioclase-perthite-quartz pegmatite rock contains 20 to 50 percent plagioclase, 20 to 35 percent perthite, 20 to 30 percent quartz, and as much as 5 percent accessory minerals. The common accessory minerals are muscovite, tourmaline, biotite, and apatite, with occasional gamet, sillimanite, and yellow lithia mica. The rock averages 7.60 percent $\mathrm{K}_{2} \mathrm{O}$ and 3.16 percent $\mathrm{Na}_{2} \mathrm{O}$ (table 1 ).

Considerable textural variation is found in the pegmatite that occurs as layers, and the diameters of the largest grains range from a few inches in one outcrop to several feet in another. Typically. large crystals of perthite and quartz, a foot or more in diameter, occur in a finer-grained groundmass of plagioclase and quartz. Plagioclase crystals larger than an inch in diameter are rare. Tourmaline and muscovite crystals occur both in the finer-grained groundmass and as large crystals, Biotite, sillimanite, and yellow lithia mica occur in aggregates that rarely exceed a few inches in diameter. Apatite and garnet grains average less than 0.1 inch in diameter.

Analyses of the granite and pegmatite (table 1) show the granite layers to contain more $\mathrm{Na}, \mathrm{Ca}, \mathrm{Fe}$, and $\mathrm{Mn}$; and less $\mathrm{K}$ and $\mathrm{Ba}$ than the pegmatite layers.

\section{Color layering}

Color layering (fig. 6), which occurs only in the granite, is formed by numerous, thin, parallel layers of quartz, tourmaline, or garnet grains. The layers are a fraction of an inch thick and appear in outcrop as parallel light and dark bands. In most places the color layers are parallel to the textural layers, but in a few places they are at a high angle to the textural layers. 


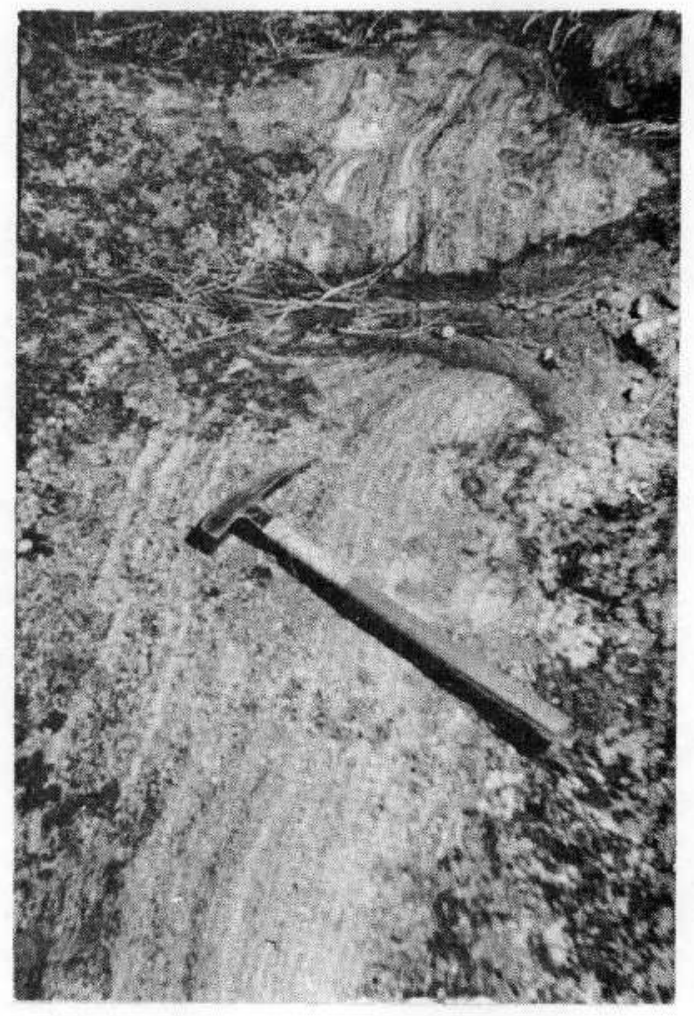

F1gure 6.--Color layering in a thick layer of leucocratic soda granite in the Calamity Peak mass. The dark layers are predominantly quartz and the light layers are predominantly feldspar. The pick is 14 inches long. 


\section{Transgressive layering}

Transgressive layering is characterized in the field by a cross-cutting relationship to the host rock and by sharp contacts, also by high perthite content and very conse grain size. It consists of a series of parallel dikes or segregations of perthite-quartz pegmatite or less commoniy plagioclase-perthite-quartz pegmatite. The dikes pinch and swell erratically, and locally are discontinuous, It is most prominent in areas where color and especially textural layering are obscure. Where transgressive layering does occur with the other types of layering, it generally cross-cuts them. In the field it is locally indistinguishable from textural layering on the one hand and unzoned pegmatite on the other.

In most outcrops only one or two of the three types of layering can be seen, Color layering and textural layering are generally parallel to each other, but transgressive layering generally crosses the other two. Textural layering is generally parallel to the contacts of the granite-pegmatite masses with the schist, even where the schistosity is discordant with the contact.

All three types of layering are well exposed in an area of several acres in the SE $1 / 4 \mathrm{NW} 1 / 4 \mathrm{sec}$. 20. The textural layering trends $\mathrm{N}_{0} 0^{\circ}-40^{\circ} \mathrm{W}_{0}$ and $\operatorname{dips} 47^{\circ}-90^{\circ} \mathrm{sW}$.: the a verage strike is $\mathrm{N}_{0} 12^{\circ} \mathrm{W}_{0}$, and the dip is $70^{\circ} \mathrm{SW}$. Tranggressive layers in this area are abundant and have variable trends, but the most prominent set, consisting of unzoned plagioclase-perthite-quartz pegmatite, strikes $\mathrm{N}_{\mathrm{v}} 3.0^{\circ}-40^{\circ} \mathrm{E}$. and dips $50^{\circ}-90^{\circ} \mathrm{SE}$. The closely-spaced parallel sheets are from a few inches to several feet thick. In one outcrop the color layering strikes $\mathrm{N}_{\mathrm{s}} 10^{\circ} \mathrm{W}$, and dips $38^{\circ} \mathrm{sW}$, but elsewhere it is conformable with the textural layering of the area. The dark color in the layers is here formed principally by tourmaline.

\section{Pegmatite}

A few of the pegmatites fn the area, called zoned pegmatites and described individually, are characterized by distribution of the minerals into distinct concentric zones as described by Cameron and others (1949, p, $16-70$ )

Most of the pegrnatites in the schist, such as Pegmatite 10 (fig, 2 and table 2), although classed as unzoned pegmatites, show an imperfect zoning They generally have a well defined, fine-grained border : 


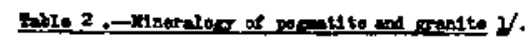

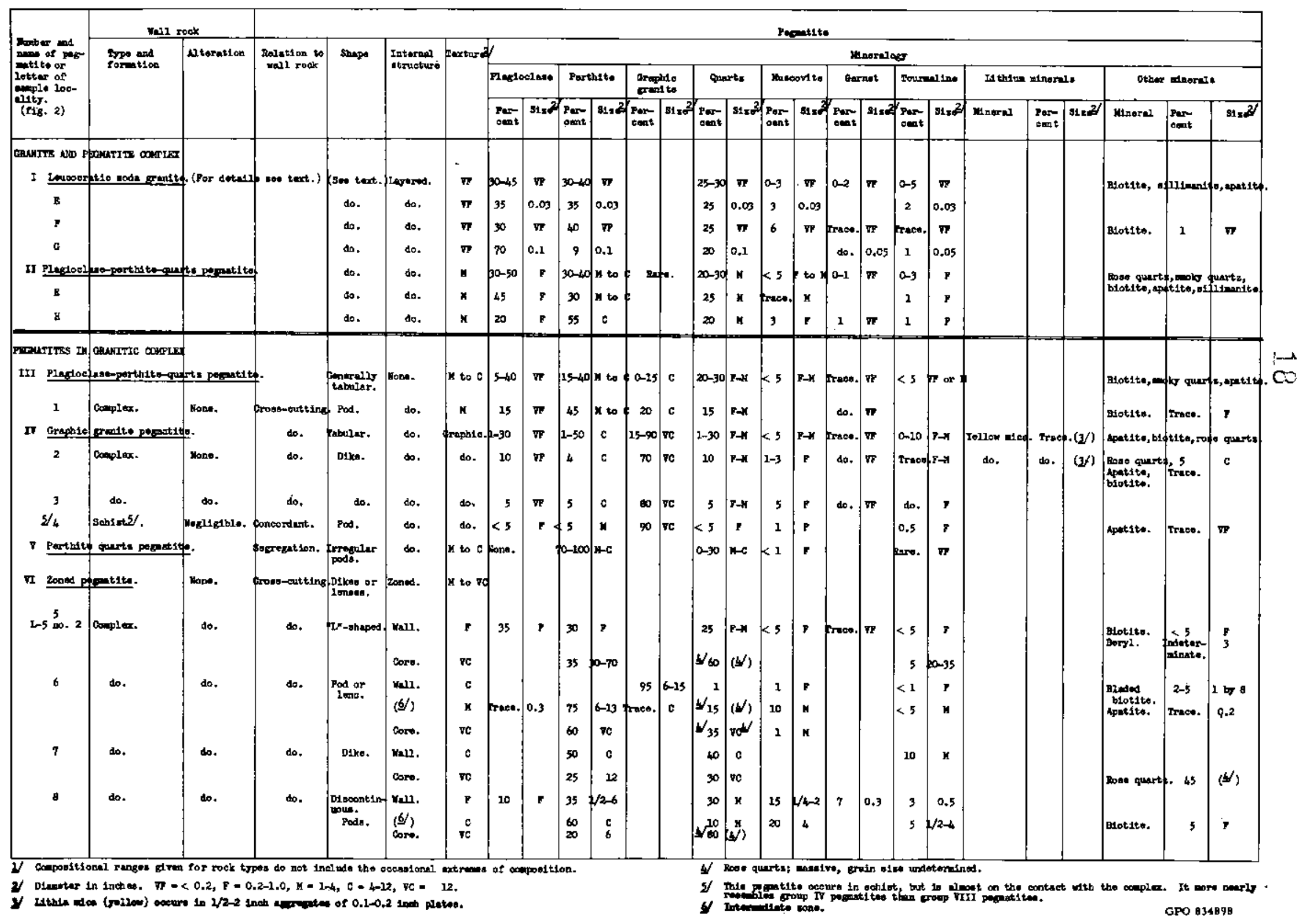




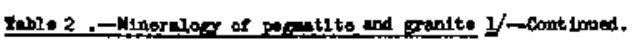

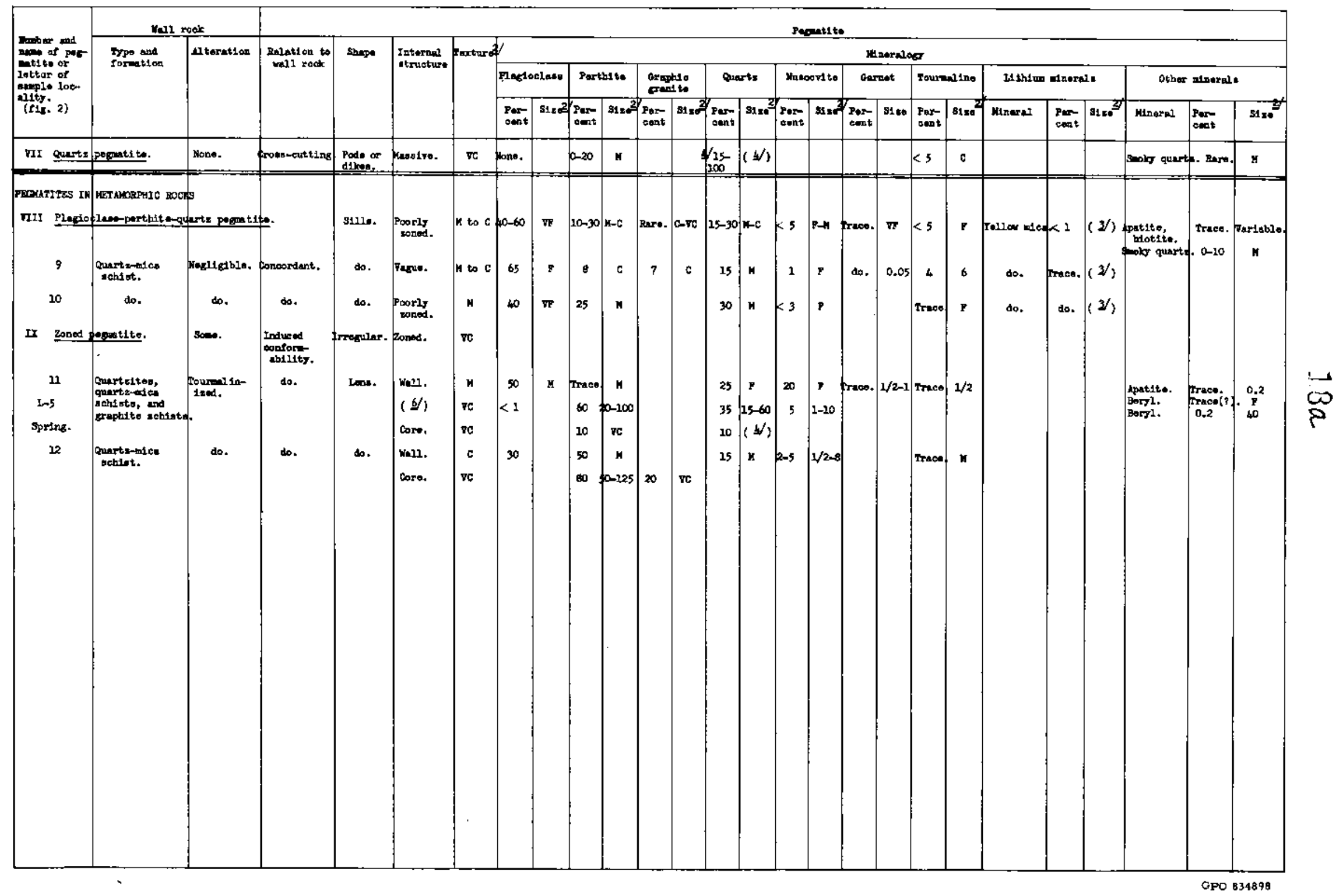


zone, about, 1 fnch thick in which individual ginitus are 0.05 to $0.2 \mathrm{fnch}$ in diameter. Muscovite tends to be most abundant in a poorly developed wall zone near the outside walls of the pegmatite; large perthite and quartz crystals form a poorly developed core. Most of the quartz is milky white, colorless, or a very pale rose.

All gradations can be found from imperfectly zoned pegmatites to well-zoned pegmatites. The zones in even a well-zoned pegmatite rarely have sharp boundaries, but the type and proportion of minerals clearly change from zone to zone. The zones are arranged concentrically and conform roughly to the shape of the pegmatite.

In naming the pegmatite rocks, the characteristic minerals are listed in order of abundance, with the most abundant mineral first. Table 2 gives details of mineralogy and texture. The unzoned pegmatite layers in the granite-pegmatite complex are plagioclase-perthite-quartz pegmatite. Most of the pegmatite sills" In the schist and many of the fracture fillings in the granitic rock are also plagioclase-perthite-quartz pegmatite. A few graphic granite pegmatites occur in the schist, but they are more common as fracture fillings in the granitic masses. Small pod-like segregations of perthite-quartz pegmatite are abundantly scattered throughout the granite-pegmatite complex, Quartz-perthite pegmatites occur as fracture fillings in the granite-pegmatite complex. The zoned pegmatites, whether in the schist or the granite-pegmatite complex, have an overall composition similar to the plagioclase-perthite-quartz pegmatite. The outer zones are rich in plagiociase and muscovite, and the inner zones are rich in quartz and perthite.

All the zoned and unzoned pegmatites occurring outside the granite pegmatite complex are shown on the map (fig 2). Only the zoned pegmatites and a few of the distinctive unzoned pegmatites within the granitepegmatite complex are shown. 


\section{Unzored pegmatite}

Plagloclase-perthite-quartz pegmiatfe ${ }^{\circ}$--Plagioclase-perthite-quartz pegmatite is the most abundant type of pegmatite in the metamorphic rocks of the Calamity Peak area. It occurs as sills and dikes and is similar in texture and composition to the pegmatite that occurs as layers in the granite-pegmatite complex Individual pegmatite bodies are as much as 1,500 feet long.

Graphic gramite-plagioclase-quartz pegmatite. --The graphic granite-plagioclase-quartz pegmatites occur mainly as dikes in the granite-pegmatite complex. They contain 50 to 80 percent graphic granite in crystals 6 inches to 6 feet in maximum dimension. The texture and composition of the remainder of the rock is similar to that of the plagioclase-perthite-quartz pegmatite,

Perthite and perthite quartz pegmatite. --The granite-pegmatite complex contains numerous small irregular pods and stringers of perthite, or perthite and quartz. The pods are seldom wider than the coarsest perthite crystals in the pod, but several pods may unite to form stringers several feet long. Most of the perthite crystals are between 2 and 10 inches in diameter. Quartz, where present, forms less than 20 percent of the rock. The quartz grains are about one-fourth the size of the perthite crystals.

Quartz-perthite pegmatite ${ }^{-}$-Dike-like rose quartz bodies from a few inches to several feet thick can be traced for tens to hundreds of feet through granite-pegmatite complex. Although vein-like in their distribution, most of these bodies consist of massive rose quartz with a few large perthite crystals near the outer edge-- a typical pegmatite texture. Some bodies, however, are pure quartz and may represent tue veins. Many gradations can be found from rose quartz veins to quartz-perthite pegmatite. In a few places the rose quartz veins can be traced along the strike into the core of zoned pegmatites. The rose quartz grades from very pale grayish pink $(5 R 8 / 1)$ _ to a clear rose-pink $(5 R 6 / 4)$ _. 


\section{Zoned pegmatite}

The typicat well-zoned pegmatite consists of a series of shells or partial shells around a central core. The outer and thinnest shell is a fine-grained border zone that may be a chilled contact. Next is a wall zone th which muscovite and sometimes biotite are concentrated, Next is the intermediate zone, which constitutes the bulk of the pegmatite. The normal intermediate zone is plagioclase-perthite-quartz pegmatite, but variations are very common. The core is generally massive rose quartz bordered by very coarse perthite crystals.

Six zoned pegmatites of the Caiamity Peak area are described below, Table 2 contains detailed mineralogic data for these pegmatites. The Tery claim (fig 2) has been described by Page and others (1953, P. 195).

L-5 $\mathrm{No}_{3} 2,-\mathrm{L}-5 \mathrm{No} .2$ (pegmatite 5 of fig, 2) has been sporadically mined by Kenneth spring of Custer for minerals that can be sold to tourists. The pegmatite has been opened by an "L" shaped cut 110 feet long and 4 to 12 feet deep.

The L-5 No. 2 pegmatite is shaped like an inverted trough, each limb of the trough is a separate pegmatite and the wall zones of these pegmatites coalesce. The west pegmatite strikes $\mathrm{N}_{0} 30^{\circ} \mathrm{E}$. for 40 feet and dips $80^{\circ} \mathrm{NW}$. The east one strikes $\mathrm{N}_{0} 37 \mathrm{~W}_{\circ}$ for 70 feet and dips $53^{\circ} \mathrm{NE}$. They both are 10 to 15 feet thick. The country rock is granite-pegmatire complex. The zones in the pegmatites, from the contact inward are:

(1) plagioclase-perthite-quarz pegmatite with tourmaline, muscovite, and biotite;

(2) plagioclase-perthite-quartz pegmatite with tourmaline and muscovite;

(3) plagioclase-perthite-quartz pegmatite with tourmaline and beryl;

(4) quartz-perthite-tourmaline pegmatite (core).

The core contains massive rose quartz (60 percent), 3- to 6 -foot perthite crystals ( 35 perceht), 2-to 3-foot black tourmaline crystals ( 5 percent). 
Pegmatite $6_{6}$--A pegmatite of unknown ownership is on a low ridge of granite-pegmatite complex. (fig. 2) and has been prospected by open cuts on both flanks of the ridge. "The extremities of the pegmatite have been covered by dump, but the pegmatite seems to be a lenticular pod 50 feet long by 15 feet wide. It is exposed to a depth of 10 feet. The wall zone is composed of graphic granite ( 95 percent), biotite ( 5 percent), and traces of tourmaline and muscovite. The biotite occurs as elongate books that average 1/4 inch thick, 1 inch wide, and 8 inches long. The long axis of the biotite is perpendicular to the pegmatite contact. The perthite-quartz-muscovite pegmatite intermediate zone contains accessory tourmaline, graphic granite, plagioclase, and apatite and has a medium-grained pegmatitic texture; most of the grains are between 1 and 2 inches in diameter. Some of the perthite and rose quartz crystals are a foot or more in diameter. Badly reeved and soft muscovite occurs in 1-inch to 4 -inch books in clusters or pods 2 feet in diameter. The core of 1- to 2-foot perthite and rose quartz crystals was 6 feet thick, 12 feet wide, and 15 feet long, but three-quarters of it was removed during prospectingo

Pegmatite 7. --Pegmatite 7, (fig。 2), opened by a small prospect pit is 70 feet long and has a wall zone from $1 / 2$ to 1 foot thick, around a core of colorless and rose quartz, $31 / 2$ feet thick. Black tourmaline crystals from $1 / 8$ to 1 inch in dlameter and from 1 to 4 inches long occur just inside and perpendicular to the contact of the pegmatite with the granite-pegmatite complex. A few perthite crystals, 1 foot long, occur in the core。

Pegmatite 8. - A series of unprospected, discontinuous, lenticular pegmatite bodies occur along a fracture 750 feet long. which strikes $N_{0} 53^{\circ} \mathrm{W}_{0}$, and dips steeply southwest (fig。 2). At the west end the pegmatte is continuous for 150 feet, then becomes pod-like and discontinuous for another 300 feet The easternmost 300 feet of the fracture contains very little pegmatite. Typical pods contain the following zones:

(1) $a_{1}$ discontinuous quartz-muscovite-garnet pegmatite border zone 1-inch thick with accessory feldspar, biotite and tourmaline;

(2) a quartz-perthite-muscovite wall zone, 5 to 30 inches thick with garnet and tourmaline;

(3) a perthite-muscovite-quartz pegmatite intermediate zone 5 to 30 inches thick with tourmaline and biotite; reeved mica books average 2 to 6 inches in diameter;

(4) a core of rose quartz pegmatite 1 to 3 feet thick with a few 6-inch crystals of perthite at the edges. The cores of most podsare 2 to 10 feet long. 
$\underline{L}-5$, or Spring pegmatite. - -The Spring pegmatite (pegmatite no. 11, fig. 2). is owned by Kenneth Spring of Custer, S, Dak. It is opened by a pit 50 feet long, 30 feer wide, and 15 feet deep: The pegmatite is tabular to lenticular and is about 100 feet long and 30 feet thick. The attitude of the pegmatite is not clear, but it appears to strike east and dip $45^{\circ}$ south.

The country rock in the neighborhood of the pegmatite includes quartzite, graphitic schist, amphibolitic schist, and quartz-mica schist, The actial contact is exposed at only one point, in the bottom of the northeast corner of the curt, where the schist rolls under the pegmatite and plunges $25^{\circ}$ west At this point, the wall rock is quartz-mica-tourmaline schist.

The pegmatite consists of three main zones The wall zone, plagioclase-quartz-muscovite pegmatite, contains 4- to 6-inch caystals of cleavelandite and 1-inch crystals of quartz. The muscovite in this zone is mostly $1 / 4$ to 1 inch in diamerer, but some books are as much as 3 inches in diameter. The mica is a light ruby and most of the stieet recovered from it would be of no. 2 or no. 2 inferior quality. One-half inch crystals of beryl are reported to be present in this zone

The intermediate zone, perthite-quartz-muscovite pegmatite, consists mainly of 2- to 10-foot crystals of perthite and quartz. The perthite contains unusual dark streaks along certain crystallographic planes in the mineral, resulting fn dark gray and white layers from 0.05 to 0.2 inch thick. Books of muscovite as much as 2 feet in diameter occur in this' zone, but the mica is soft, air stained, reeved and ruled, Only a negligible percentage of this mica could be used for sheet and punch mica, One beryl crystal, about 2 feet in diameter and 3 feet long, was mined from this zone in 1940 .

A quartz core is reported by the owner to have been exposed in the floor of the pit. It is now covered by debris, although a small part of the core was observed in the walls of the pito Its shape is not accurately known. 
Pegmatite 12 (fig, 2)。--A pegmatite of unknown ownership has been mined by an open cut about $\mathbf{1 5}$ feet long, 8 feet wide, and 7 feet deep. The pegmatite is 200 feet long and contains a core of rose quartz. The pegmatite has been altered by hydrothermal solutions, leaving irregular areas of fine-grained perthite, quartz, biotite, muscovite, tourmaline, and clay.

The cut is in a roll on the side of the pegmatite, and the zonal bountaries at this point are very gradational. The outer zone contains mostly $1 / 2$ to 2 inch muscovite books, but a few books are as much as 8 inches in diameter. The core of the roll is an irregular mass of perthite crystals, 4 to 10 feet long. About one-fifth of the perthite crystals are graphically intergrown with quartz.

\section{QUARTZ VEINS}

White to gray quartz veins are very common in the schist, and are particularly abundant in the center of sec. 19 and in the northwest corner of sec, 17, They range in size from minute veinlets that follow the minor crenulations in the schist to 10 -foot massive veins that parallel or cut the schistosity at moderate angles, Most of the larger veins are in the area mapped by Langen (fig, 1) and contain sillimanite and andalusite. Smoky quartz occurs in many of the veins and large biotite flakes are commonly present in the adjacent schist.

Many of the quartz bodies in the schist, especially the thin veinlets, contain as much as 30 percent feldspar, and may be a transitional phase between typical felspathic pegmatite stringers on the one band and quart veins on the other.

SEDIMENTARY ROCKS

\section{Terrace gravels}

High-level terrace gravels cap most of the low grass-covered hills in the southwestern part of the Calamity Peak area. The maximum thickness of the deposits is not known, but a 12-foot thickness is exposed in the gravel pit in SE $1 / 4 \sec _{s} 19$ (fig, 2). The edges of the deposits thin to less than 1 foot and become indistinguishable from the finer-grained alluvium. 
Rounded and sub-rounded pebbles and cobbles make up haIf of the gravels, All of the bedrock types found in the mapped area are represented among the pebbles; but quartz-mica schist, the most abundant bedrock type, is very rare; massive quartzite and the amptribolitic rocks are abundant.

The cross-bedding of the grevels in the gravel pit suggests a source to the north.

\begin{abstract}
Hinfun and tains
Flood plain deposits cover the floors of the larger valleys and stand 2 to 6 feet above the present stream beds. Flood plain deposits and the stream gravels of the larger streams are indicated as alluvium on the geologic map (fig, $2 \%$

Talus slopes are found at the base of all of the higher cliffs in the area, but only those taluses that obscure significant geologic contacts are indicated on the geologic map (fig, 2).

\section{STRUCT URE}

In a general way the structure of the Calamity Peak area is that of a series of steeply southidipptng schists cut by large and small masses of granite-pegmatite complex, and the whole mass then intruded by pegmatites. The schis s have been warped into a steeply plunging anticline and syncline. The largest unit of granite-pegmatite complex, the Calamity Peak mass, is a dome-shaped lenticular mass with an internal layering that is also dome shaped. The mass occurs in the crest of the anticline and is partially conformable with, and partially crosscuts, the schistosity. A smaller, more sill-1ike mass of granitepegmatite complex crops out north of the Calamity Peak mass.

Three major faults trend northeast across the area and dip to the south at a high angle. The movement on them is probably of the normal type. with dip-slip movement of about 500 feet. The presence of a fourth paraliel fault is indicated.
\end{abstract}




\section{Bedding and sctistosity}

That the distribution of the various types of metamorphlc rocks (quartz-mica schists, graphitic schists, quartzites, and amphibolites) reflects otiginal bedding is confirmed by the bedding in the less abundant rocks rich in amphibole and graphite that occur in the southern part of the area. These rocks have recognizable bedding parallel to the schistosity. In the southern part of the axea, distribution of rock types and the observed bedding indicates that the metamorphic rocks of the area have been folded into a broad, open syncline on the west and a tighter, but still moderately open anticline on the east, The folds plunge 65 degrees to the south.

In the northern part of the area where the rocks are mainly quartz-mica schists the bedding is obscure, but where observed is also parallel to the schistosity. It is concluded that regional schistosity is parallel to original bedding. Therefore, the anticlinal axis of the folding in the metamorphic rocks has been projected northward on the basis of the patrern of regional schistosity.

The regional schistosity over the whole area dips steeply to the south and generally follows the bedding in the folds described above. In certain areas, however, the schistosity departs from the regional pattern because a secondary schistosity has been developed at an angle to the primary schistosity and to the bedding. In these areas which are most abundant to the northeast, the quartz-sillimanite knots are lagge and abundant and the lineation and wrinkling described below is well developed.

On the geologic map (fig. 2), the synclinal and anticlinal axes are shown, but the distribution of the types of metamorphic rocks on which they are princlpally based is not. The syncline and anticline are reflected by the pattern of the regional schistosity; secondary schistosity is generally indicated by symbols that depart from the regional pattem.

\section{Wrinkling and lineation}

In many parts of the area a secondary folding, crenulation, or wrinkling (figo 7 ) is imposed on the schistosity. Most of the wrinkles have an amplitude of 0.2 to 0.5 inch and a period of 0,5 to 1 inch, but the range in amplitude is from 0,1 to 14 inches. 


\section{7}

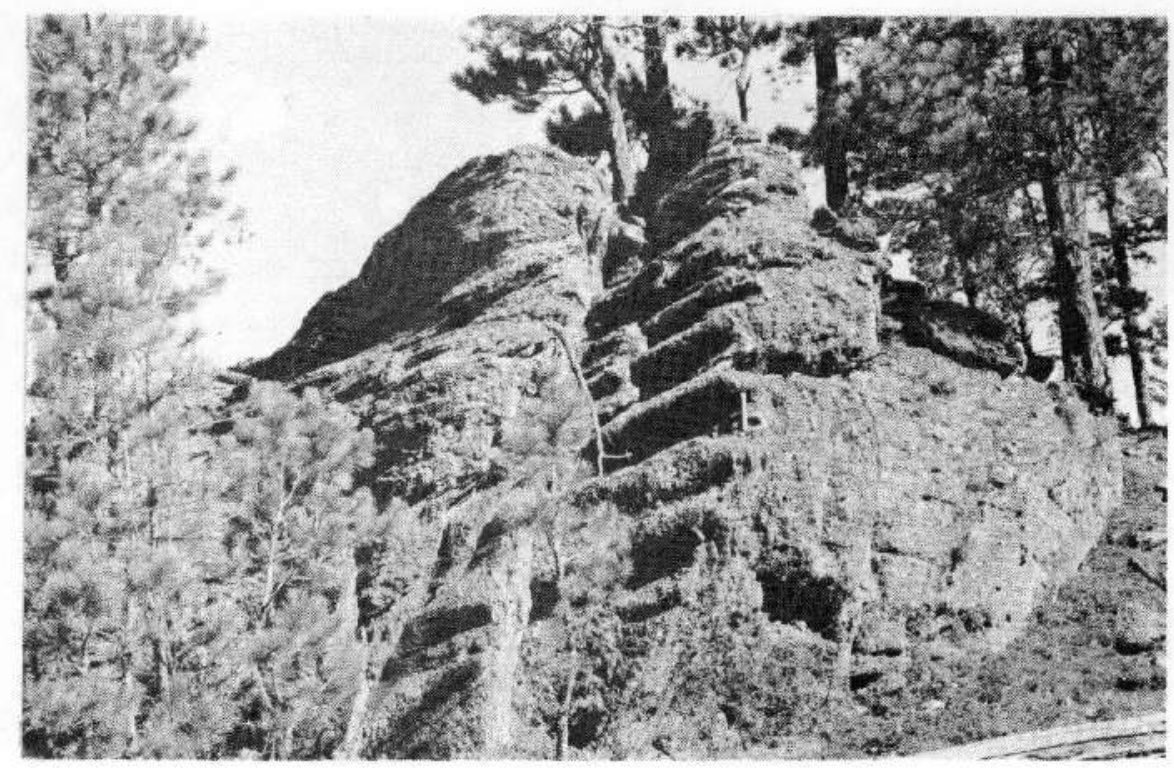

Figure 7.--Very large wrinkles in schist in the northem part of the area. Reglonal schistosity and the bedding strike N. $60^{\circ} \mathrm{W}$ and $\mathrm{d} 1 \mathrm{p} 50^{\circ} \mathrm{SW}$ (parallel to the crests of the wrinkles). A second schistosity is developed 10cally that strikes N. $67^{\circ} \mathrm{E}$, and dips $40^{\circ} \mathrm{NW}$. (parallel to the axial planes of the wrinkles). The geology pick rests on a sinuous quartz veln about 1 inch thick that follows the crenulations of the wrinkles. The knobby character of the schist is caused by quartz-sillimanite knots. 
As a result of the wrinkling the biotite and muscovite flakes, and possibly the other minerals, are alined along the wrinkles and at an angle to the main schistosity. The result is a lineation on the schistostty that is parallel to the axes of the wrinkles. In some places this lineation occurs where there is no megascopic wrinkling. The plunge of the lineation is southerly, and approximately parallel to the plunge of the large scale folds in the area, but slightly inclined toward the troughs,

In the areas where wrinkling is best developed (as in the NE $1 / 4 \mathrm{NE} 1 / 4 \mathrm{sec}_{0} 20$ ) two sets of schistosity are also commonly present. The older set parallels the regional schistosity and the wrinkles have developed on this set. The newer set parallels the axial planes of the wrinkles.

In many of the areas of intense wrinkling, quartz veinlets conform with the individual wrinkles; the resultant sinuous pattem in very distinctive (fig。 7 )。 In the SW 1/4 NE 1/4 sec, 17, sinuous quartz veinlets occur in an area of unwrinkled, uniform, schists with north-trending (secondary) schistosity. It is believed that this sinuous pattern is a relict structure from the now obliterated former wrinkling and thus identifies the final stage in the development of secondary schistosity。

\section{Igreous structures}

The granitic bodies are divided for purposes of description into three structural types, but actually all three are members of a gradational series. The large mass of granite-pegmatite complex that crops out in a roughly circular pattern around Calamity Peak will be described first, followed by the tabular bodies of the same rock to the north of Calamity Peak, and finally the sills and dikes of pegmatite.

The areas between the large masses of granite apegmatite complex and the schist consist of an alternating sequence of pegmatite sills and schist screens \{septa or tongue-like projections of wall rock in and between the pegmatites). The number and concentration of the pegmatites decrease outward away from the main mass as the size and extent of the schist screens increase, so that the change from massive granitepegmatite complex to schist occurs over a zone several hundred feet thick. At some of the individual contacts within this zone, the same interfingering of the two rock types occurs on a small scale yet even on the smaller scale, each contact is sharply defined and every fragment of rock can be tabeled as either schist or granitic rock. 


\section{Calamity Peak granitic mass}

Granite-pegmatite layered rock complex is exposed around Calamity Peak in a roughly circular area one mile in diameter. The relief is about 600 feet. Exceptionally good exposures provide data in three dimensions on this dome-shaped shell with a schist core. The layering in the granite-pegmatite complex and the contacts of the mass on the western, southern, and eastern sides are parallel with each other and with the schistosity and bedding, Underneath the mass and all around its northern half, however. the schistosity is at a high angle to the contacts and the internal layering (figs, 2 and 3 .

A deep east-trending valley cuts through the heart of the mass (just north of Calamity Peak) and exposes a schist core completely surrounded on all gides by granite-pegmatite complex. The schist contains abundant pegmatites, 2 to 20 feet thick; both the pegmatites and the schistosity strike east and dip $40^{\circ}$ to $70^{\circ}$ south into the granite-pegmatite complex above and on both sides, The area of this schist inller has ridges, knobs, and cliffs as much as 100 feet high, which are capped by an increasing proportion of granite-pegmatite complex upward. Pegmatite dikes branch and thin downward, and schist gcreens end abruptly upward against the granite-pegmatite complex (figo 8).

The layering in the granite-pegmatite mass at Calamity Peak, like the mass itself, is domal and dips outward from the schist core. Pendants and inclusions of schist in the granite-pegmatite mass maintain the orientation of the adjacent schist country rock, without regard to the domal structure of the mass itself.

The extreme northem contact of the Calamity Peak mass is sharp, without the normal transition zone. It is assumed to be a fault (souiheastern faults, fig. \$.

In summary, the granite-pegmatite complex at Calamity Peak is a domed, tabular intrusive, probably cut off on the north by a normal fatt. As a crude generalization, the north half of the mass appears to transgress regional structures and the south half parallels them. The internal layering is generally conformable with the external contacts. 


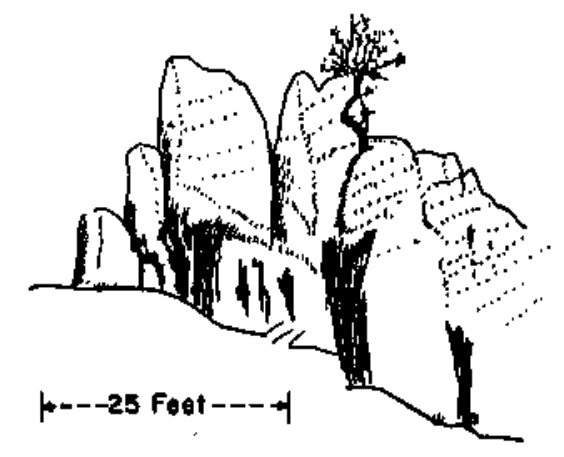

Figure 8.--Outcrop in the schist core of the Calamity Peak mass showing schist (dark areas) cutting out upwards against layered granite-pegnatite complex. V1ew looking east. Schistosity strikes N. $750 \mathrm{E}$. and dips $65^{\circ} \mathrm{SE}$; layering strilces $\mathrm{N} .8 .5^{\circ} \mathrm{F}$. and dips $180 \mathrm{NW}$. 
Tabular bodies

North of the Calamity Peak mass, tabular bodies of layered granite-pegmatite complex are as much as 500 feet thick. The attitude of the bedding in this area is unknown but if bedding is parallel to primary schistosity, as is believed to be the case, the bodies are sills $s_{a}$ Except as noted in the following paragraph, the bodies are generally concordant with the schistosity and the internal layering is parallel to both the contacts and the schistosity.

In the NE $1 / 4$ of $\sec _{a} 17$, the structure of the thickest of the tabular bodies is, neglecting minor complications, probably anticlinal. Although this is not readily apparent from the map (fig. 2), it is suggested by the general distribution of the granite-pegmatite complex and by the layering (fig. 5). In the southeast corner of sec, 8 the layering is too vague to show on the illustrations. but suggests a general dip to the east. Minor crenulations are superposed on the major structure, and the layering, schistosity, and contacts are locally at high angles to each other $r_{a}$ On the map (figo 2), the anticlinal axis in the metamorpbic rocks is shown about 1,000 feet west of the anticlinal axis of the layering. This interpretation is somewhat subjective.

\section{Pegmatites}

Although a few of the bodies of granite-pegmatite complex are small and sill-like, and similar to pegmatires, with which they form a gradational series, the true pegmatites are characteristically smaller, unlayered, and granite-free, Most of them are crudely zoned,

Pegmatites that cut the Iayered granite-pegmatite masses are of four types. All four types can efther cross-cut or parallel the layering. In order of abundance they are (1) pod-like perthite-quartz segregations--numerous, but small, (2) tabular or pod-like graphic granite pegmatites, (3) zoned pegmatites with rose quartz cores that form thin, tabular masses that pinch and swell, and (4) quartzperthite pegmatites or rose quartz veins, rarely more than 2 feet thick many of which can be traced for several hundred feet. 
The pegmatites in the schist are generally tabular and concordant with the schistosity. Where bedding can be recognized, they are sills. A secondary schistosity has been induced at the borders of the pegmatites, and the schist appears to wrap around the ends of the pegmatites and to conform to all minor irregularities along the pegmatite contacts fig 9\%. The plunge of the pegmatites and of the minor rolls on the pegmatite contacts is parallel to the plunge of the wrinkling. the folds, and the biotite lineation in the schist.

Most of the pegmatites in the schist country rock are plagioclase-perthite-quartz pegmatite, and most of them show a crude zoning. Numerous gradational stages from crudely zoned to well-zoned pegmatites can be recognized Crudely zoned pegmatites are many times more abundant than well-zoned pegmatites.

Most of the unzoned or crudely zoned pegmatites are close so the granite-pegmatite masses. The zoned pegmatites are less rigidly controlled by the locacion of the granite pegmatite masses and may be strongly influenced by some secondary control, such as a favorable bed or formation in the country rock. For example, several of the commercial pegmatites near Calamtity Peak are in areas that are richer in quartzite, amphibolite, and graphitic schist. This lation may be only coincidental, Careful work over a large area should reveal the truse secondary control, whatever it may be.

\section{F}

Three prominent parallel faulte (fig. 2) stpike northeast across the area; one or more other large faults may be present. The middle falt is composed of two en échelon fractures: the displacement on one decreases as the other increases. The strike is $\mathrm{N}_{0} 50^{\circ} \mathrm{E}_{\mathrm{a}}$ and the topographic expression suggests a steep southeast dip. The position and structure of the granitic masges on opposite sides of the fault suggest a normal dip-slip movement of about 500 feet

The northwestern fault is poorly exposed Lacking evidence to the contrary, it is assumed to be a nocmal faulf dipping to the sogtheast like the fault already described 


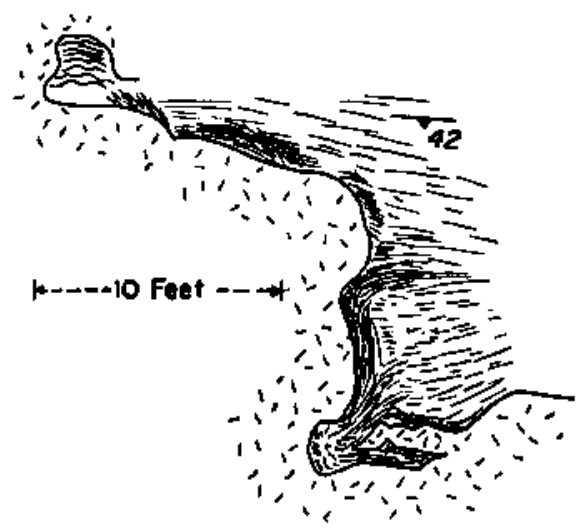

Figure 9.--Plan view of contact of pegmatite and schist south of Calarnity Peal. The regional trend of the schistosity is locally destroyed and the new schistosity is conformable to the contact. 
The presence of the southeastern of the three fauits is suggested by the abrupt northern termination of the Calamity Peak mass, by the discordance of the internal layering (see fig. 2 and section B-B ' fig. 3), and by the break in the trends of the schistosity. The direction of movement of this fault is unknown, but It is assumed to be a normal fault like the middle fault.

A group of several minor faults are shown on the map between the middle and southeastern of the three parallel faults (fig, 2). These probably represent the southwest end of a fourth parallel fault as indicated on section B-B' (fig. 3 .

\section{ORIGIN OF THE GRANITIC ROCKS}

The principal objective of the mapping program in the southern Black Hills was to set up a series of criteria by which unexposed or unexploted, commercial pegmatites could be distinguished from the very numerous non-commercial pegmattes, To do this the author started mapptag in the Calamity Peak area to try and determine the relations between the Harney Peak granitic mass and the commercial pegmatites, and another party (Lang and Redden, 1953) started mapping in an area of commercial pegmatites, For the Calamity Peak area, field work is just well started, and the ideas are still in the formative stage. Any attempt to state conclusions is premature, but sufficient work has been done to suggest certain trends of thought.

First, it seems probable that continued field work will indicate criteria that can be used to determine areas in which commercial pegmatites are abundant. The chatacter of the country rock and the distance and relationship to the main granitic masses will be important

Second, the so-called "granitic batholith" around Hanney Peak (and Calamity Peak) is actually a series of thick tabular bodies of granite-pegmatite complex. Moreover, these bodies are gradational in texture, structure, and mineralogy with the pegmatites a including the commercial pegmatites.

Third, the masses of granite-pegmatite complex and the pegmatite bodies have a related origin, but this origin has not yet been fully determined. The evidence that the pegmatite bodies are intrusive is reasonabiy clear-cut, but the mode of origin of the associated masses of granite-pegmatite complex is not at all clear. 
Fourth, the key to the origin of the granite-pegmatite masses lfes in a careful study of the layering in these masses and of the structurs 1 relations between these masses, the country rock, and the adjacent pegmatite bodies, Any acceptable hypothesis for the origin of the granite-pegmatite masses should be compatable with the following observations:

1. The granite pegmatite complex occurs in tabular masses that, in a general way, are conformable or concordant with the schistosity, but locally, as in the Calamity peak mass, the structures are very different.

2. Textural, color, and transgressive layering occur in the ganite-pegmatite complex and, in a general way, this layering is parallel with the contacts and with the schistosity, but local rather marked variations from this conformity are present.

3. The wrinkling in the schists probably is related to the formation of a secondary schistosity, Locally the secondary induced schistosity wraps around the pegmatite bodies and conforms to major and minor variations in the shape of the pegmatite.

4. The pegmatite silis are more abundant along the contacts of the larger masses of granite-pegmatite complex than elsewhere.

5. Rock transitional between grandte and schist may be present in a few places, but if so, the transItional stages are incomplete. 
Several different modes of origin, ranging from magmatic Intrusion to dry granitization have been considered to account for the above features. At the present incomplete state of the field knowledge, none allows a simple explanation of all the observations. At least one set of observations seems to be in direct opposition to each hypothesis. A combination of several processes will probably be necessary to account for all of the observed facts.

\section{MINERAL RESOURCES}

\section{Pegratites}

Pegmatites in the Black Hills have been mined for beryl, feldspar, mica, spodumene, amblygonite, lepidolite, tantalum, and souvenir rock for tourist sale. None of the pegmatites in the Calamity Peak area were being mined in 1950, probably because they are too small or too low grade. The locations of the prospects and mines of the area are indicated on figure 2 and their mineralogy is tabulated on table 2. Reference should be made to the section on Pegmatite for mineralogic descriptions of the pegmatites and for detailed descriptions of the geology of the zoned pegmatites nos, 5,6,7,8, 15, and 16 .

Several pegmatite mines in the Buckhorn area, but just outside the Calamity Peak area, have furnished industrial minerals including the Victory, Victory No. 1, Custer Mica Lode No, 1 and No. 2 , L-5 No. 3 and No, 4, Mica Queen, Tin Key, Harbach (Lucky Jerry), and Clímax mines, These have all been mentioned or described by Cameron and others (1949), or by Page and others (1953).

Bery 1

Beryl has only been found in two pegmatites in the area. The Spring pegmatite (pegmatíte 11, fig. 2) is reported to have produced 3.4 tons of beryl from three crystals. Crystals of beryl were also reported to have been found in the $L-5$ No. 2 (pegmatite 5, fig。 2 ) and sold as souvenir rock, In the intermediate zone of L-5 No. 2 pegmatite the writer saw one aggregate containing several crystals of beryl; their total weight was about one pound. No other beryl prospects were noted, but the field work was stopped before the more favorable, adjacent areas could be studied, 
Spectrographic analyses (table 1) indicate that the granite-pegmatite complex contains about 0.001 percent BeO, corresponding to about 0.01 percent beryl, however, beryl was not identified in these samples, Pegmatites filling fractures within the granite-pegmatite complex probably contain a somewhat higher content of beryllium. Unzoned or poorly zoned pegmatites in the schist country rock of the Black Hills district have been found to contain minor amounts of beryl. The zoned pegmatites generally contain moderate amounts of beryl which can be recovered as a byproduct of mining operations for feldspar or mica.

The presence of beryl in the granite-pegmatite complex, in the non-commercial unzoned pegmatites, and in the zoned pegmatites cannot be clearly understood until the Buckhorn area is completely mapped. Further work in this area might result in finding an areal relationship between the richer beryl pegmatites and the granite-pegmatite complex which might be used as a gaide for prospecting, both in this and other beryl-bearing areas. The best beryl prospects are known to be confined to certain mineralogical or structural types of pegmatites and the recognition of any areal, structural, or stratigraphic control of these types would aid greatiy in prospecting for beryl pegmatites.

\section{Mica}

The Terry claim (fig, 2), a mica mine, is described and illustrated by Page and others.

(1953, P. 195). Its $1943-45$ production is given as slightly less than 350 pounds of sheet mica

(Page and others, 1953, p. 195). The Spring pegmatite (pegmatite 11, fig. 2) yielded less than 10 pounds of trimmed sheet and punch mica during the same period ( $P$ age and others, 1953, P. 25) but has had a production of 75 tons of scrap mica _/. Pegmatite 6 contains pods of book mica near its borders,

_/ spring, Kenneth, owner, published with permission.

and a few pounds of sheet-bearing mica have been stockpiled on the dump. The inica is reeved. and soft and none is knowri to have been shfpped. Pegmatite 8 and 12 (fig, 2) also contain some large mica books, but not in sufficient quantity to be minable in 1950 . Pegmatite 12 has been prospected, but pegmatite 8 has not 
Feldspar

Most of the prospecting in the Calamity Peak area has been for feldspar. The coarse perthite crystals in many of the pegmatites could be hand sorted and shipped, but the fact that they are not being mined suggest that feldspar is more abundant in other pegmatites in the Black Hills area. The Spring pegmatite (pegmatite 11, fig. 2) is reported to have yielded 675 tons of feldspar _.. There is no production

_ Published with permission of owner.

record for pogmatite 12 fig. 2) but a small tonnage of feldspar may have been shipped.

Pegmatites 1, 5, 6, 7, 8, 9 and 10 (fig. 2) contain feldspar but were not being mined in 1950.

Some parts of the granite-pegmatite complex contain abundant perthite-rich pegmatite and are potential, large, sources of feldspar, provided it can be recovered by milling for example, at sample area $H$ (fig. 2) an exposure of at least 60,000 square feet contains 30 percent feldspar in crystals from 2 to 6 inches in diameter.

Graphic granite pegmatites also are potential, large sources of potash feldspar and silica if economic milling and flotation methods could be devised and adopted. Four closely spaced pegmatites illustrate the order of magnitude of the tonnages available. Pegmatites 2 and 3 (fig. 2) are 600 feet apart and in the granite-pegmatite complex and a third pegmatite lies between them. Pegmatite 4 (fig. 2) is 1,000 feet west of pegmatite 2 and in schist. These four pegmatites contain a minimum of 30,000 tons of rock composed of 60 to 70 percent perthite and 20 to 25 percent quartz. Many similar pegmatites can be found elsewhere in the area and all could be treated at a single mill.

\section{Other pegmatite minerals}

The L-5 No, 2 (pegmatite 5, fig. 2) has been mined for souvenir rock, Rose quartz, smoky quartz, beryl, mica books, and large black tourmaline crystals are mined and sold to the tourist trade. Several smaller prospects in the Buckhorn area have also yielded some souvenir rock.

The only lithium minerals that have been found in the area mapped are minor traces of yellow lithia mica, No tin or tantalum minerats have been observed. 


\section{Resources}

The reserves of recoverable beryl in pegmatites is small (table 3); 1arger reserves of recoverable beryl in the Black Hills are in immediately adjoining areas.

The total beryllium resources of the Calamity Peak area are very large, but the grade is too low for these to be of economic significance. The beryl resources in the granite-pegmatite complex of the area, based on the very inadequate figure of the beryllium content of this complex (table 1), are quite large. The dome-shaped Calamity Peak mass, outcrops over an area of 30,000,000 square feet and probably continues down locally to a depth of 500 feet. The mass immediately north of Calamity Peak also has a domal shape and outcrops over an area of $6,000,000$ square feet and is probably about 150 feet thick. In addition to the above surface material, these units dip outward and downward at about $40^{\circ}$ and $70^{\circ}$ on three sides as tabular masses. Although the thickness and extent of these units are highly variable, together they probably have a length of about 10,000 feet, average about 200 feet thick.

Table 3, though not a complete tabulation of the pegmatite resources in the Calamity Peak area, provides an estimate of the resources of the best deposits in several types of pegmatite and granite-pegmatite bodies.

Sample $\mathrm{H}$ represents the best of the perthitic feldspar material in the granite-pegmatite complex. Pegmatites 2,3 , and 4 indicate the type of rock that is available in the pegmatites that contain a high proportion of graphic granite. Deposits of this type could be used if a mill is established to separate feldspar and silica.

The mica reserves are not considered significant because either the proportion of cobbable material of sheet or punch grade is very low, or the tonnages are small, or both.

\section{Gold}

Small placer and vein deposits are known in this part of the Black Hills. The origfnal gold discovery by the Custer Expedition in $\mathbf{1 8 7 4}$ is reported to have been made along French Creek, southeast of Calamity Peak. 


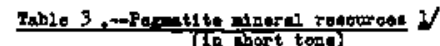

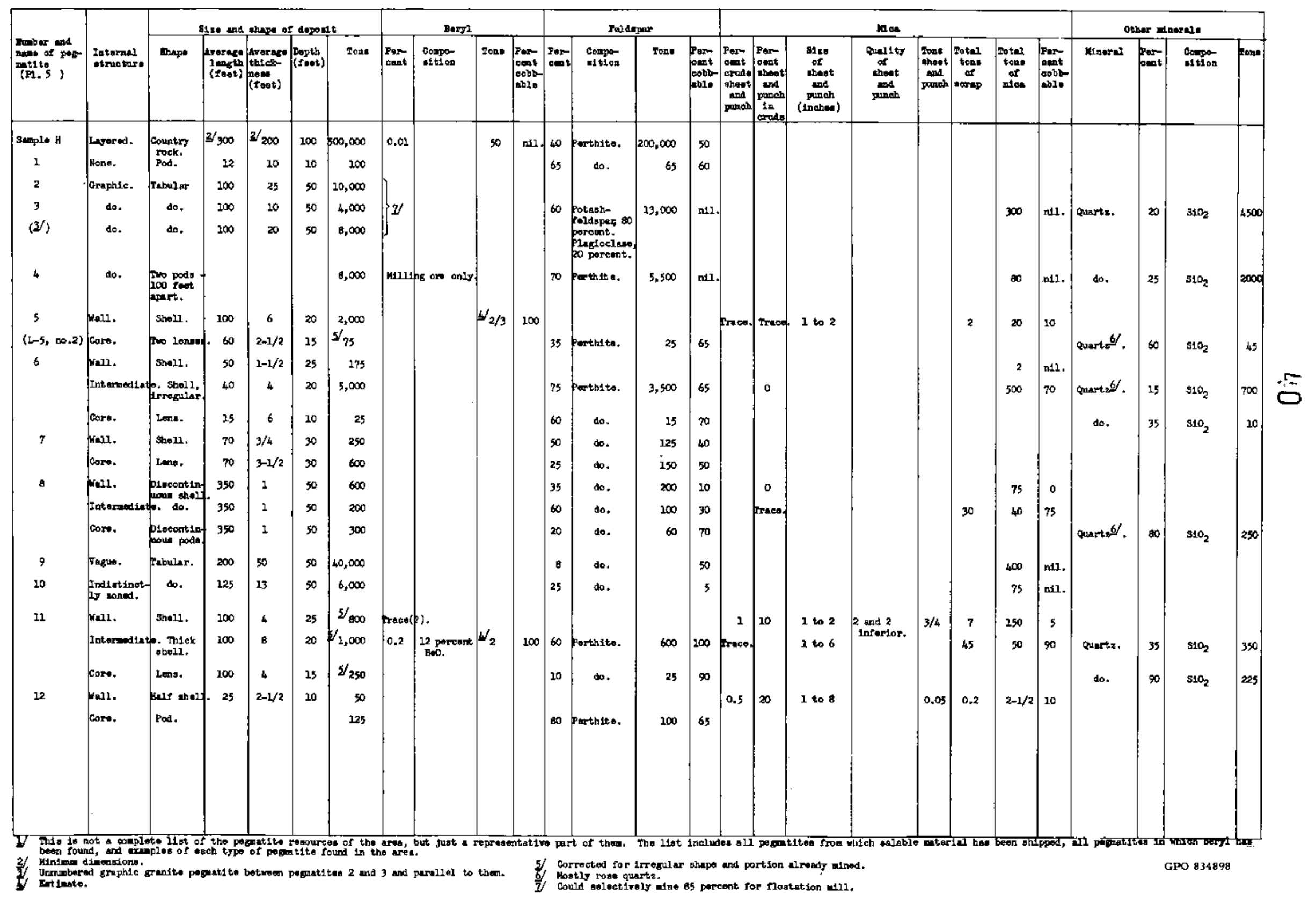


The surface exposures at the Wild Rose gold mine (fig, 2) in the NW 1/4 sec. 17 was examined briefly by the author. The mine has been described by $P_{\alpha}$ T. Allsman (1940, Pa 134-135), Gold occurs in quartz and also has been reported in the contorted wall rock schist. Three samples collected of the vein material and three of wall rock schist astayed $/ 0.01$ ounces or less of gold per ton. Two of the samples

/ Charles Bently, assayer, Engineering and Mining Experiment Station, South Dakota School of Mines and Technology, Rapid City, South Dakota。

were taken from a small surface prospect near the shaft, and the others came from the dump.

Placer gold is reported (Allsman, 1940, p. 138-139; Connally, 1933) in the stream gravels and high terrace gravels of the Black Hills. The groupscof dististered frospects in the southwest corner: of the mapped area (fig, 2) are in smail gravel deposits of this type. The gold content is unknown.

\section{Gravel}

A small gravel pit is in the SE $1 / 4$ sec $_{\text {. }} 19$ (fig. 2). Additional gravel beds are present in the area, but all are probably thin. Those in the extreme western part of the area are the thickest and, therefore, most promising as a source of gravel, 


\section{LITERATURE CITED}

Allsman, P. T., 1940, Reconnaissance of gold-mining districts in the Black Hills, S. Dak,: U. S. Bur. Mines Bull. 427, p. 134-135, 138-139。

Cameron, $E_{*} N_{*}$, Jahns, R, H, McNair, A, H., and Page, L. R., 1949, Internal structure of gramitic pegmatites: Econ. Geol, Mon, 2 .

Connally, J. P., 1933, Geologic history of Black Hills gold placers: South Dakota Geol. Survey Rept. Inv, no. 16.

Darton, N. H., and Paige, Sidney, 1925, U, S, Geol. Survey Geol. Atlas, Central Black Hills folio (no. 219).

Harker, Alfred, 1939, Metamorphism, Methuen, London, 2d edition, p. 229.

Lang, A. Ja, Ir., and Redden, J. A., 1953, Geology and pegmatites of part of Fourmile area, Custer County, S. Dak。: U. S, Geol. Survey Circ, 245.

Page, L。 R., and othew, 1953, Pegmatite investigations 1942-1945, Black Hills, South Dakota: U. S, Geol. Survey, Prof, Paper, No, 247, 228 p. 


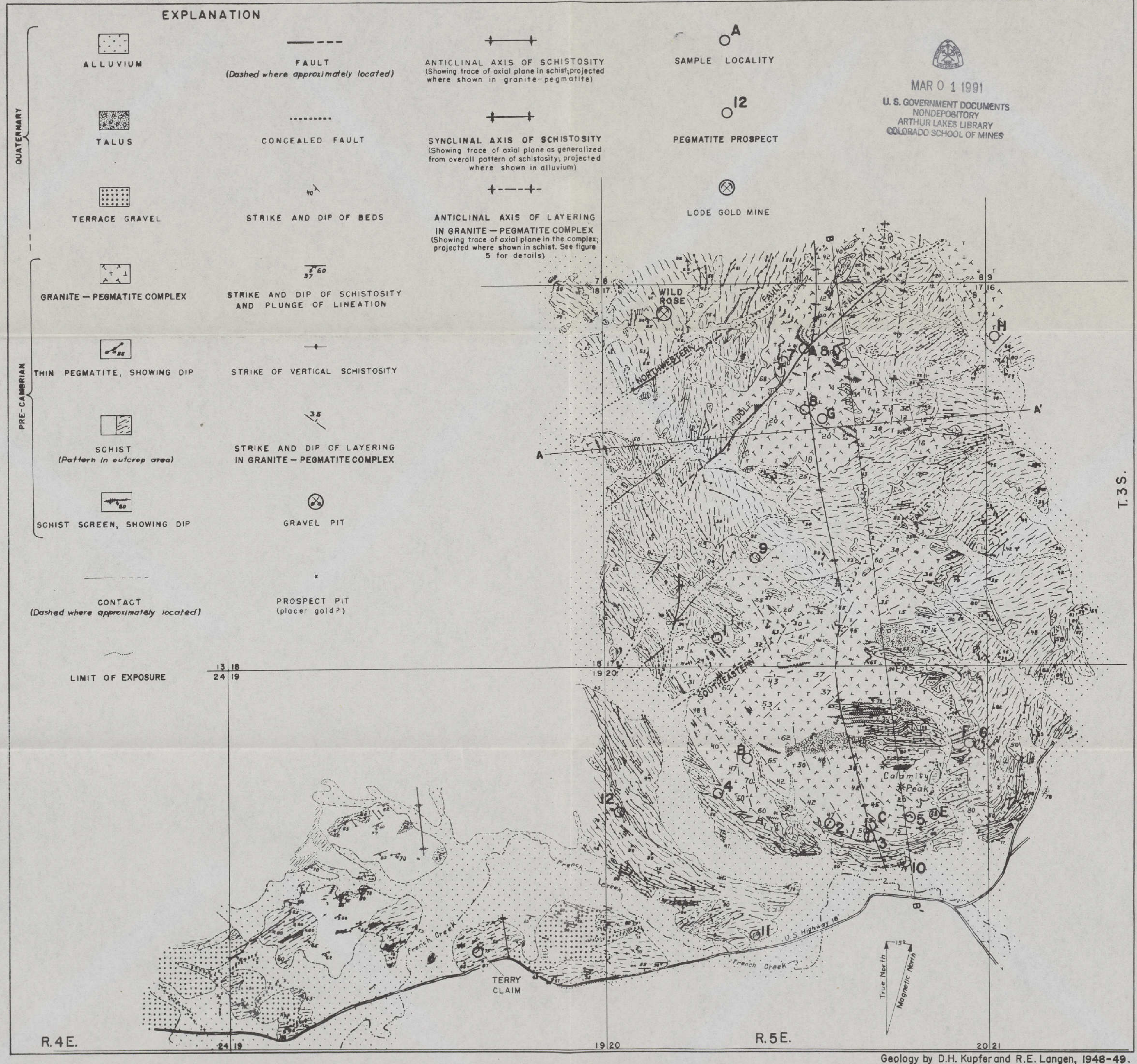

FIGURE 2. - GEOLOGIC MAP OF THE CALAMITY PEAK AREA, CUSTER COUNTY, SOUTH DAKOTA. 



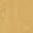

